\title{
Comparison of Ion Channel Gene Expression in the Sinus Node of the Human, Rabbit, Rat and Mouse
}

\author{
Jue $\mathrm{Li}^{1}$, Halina Dobrzynski ${ }^{1}$, Ming Lei ${ }^{2}$, Mark R Boyett ${ }^{1}$ \\ ${ }^{1}$ Cardiovascular Sciences, University of Manchester, UK \\ ${ }^{2}$ Department of Pharmacology, University of Oxford, UK
}

\begin{abstract}
Small animal species (e.g. mouse) have a faster heart rate than large animal species (e.g. human). We have looked for the reason from the functional level to the gene level in the human, rabbit, rat and mouse using a 'metaanalysis' approach. For example, review of the literature shows that, in isolated sinus node cells, the spontaneous rate is $4.6 \times$ faster and the action potential is $2.4 \times$ shorter in mouse than in human. Although data on ionic currents are limited, data suggests that the density of the funny current $\left(I_{f}\right)$ is $\sim 5 \times$ higher in mouse than in human, (Q10 of 1.38 was used to correct temperature differences among studies). Data on ion channel mRNA expression ( $q P C R)$ in the sinus node for the four species were collected from different research groups. To compare data, we either normalised to the $N a_{v} 1.5 \mathrm{mRNA}$ level (in atrial muscle) or the $\mathrm{Ca}_{v} 1.2 \mathrm{mRNA}$ level (in sinus node). Although different housekeeper genes were used (18S, 28S, HPRT), comparison of different data sets on the same tissue but with different housekeeper genes suggests that this is unimportant. In the sinus node, many ion channels were more highly expressed in mouse than in human, for example, HCN1 (by 18×; partly responsible for $I_{f}$ ), HCN2 (by 26×; partly responsible for $I_{f}$ ), HCN4 (by $7 \times$; partly responsible for $I_{f}$ ), Ca 3.1 (by 16×; responsible for the T-type $\mathrm{Ca}^{2+}$ current, $I_{C a, T}$ ), RyR2 (by 6×; $\mathrm{Ca}^{2+}$-handling molecule) and SERCA2 (by 70×; $\mathrm{Ca}^{2+}$-handling molecule). It is concluded that the mouse heart rate is faster, because sinus node ion channel expression is higher in mouse.
\end{abstract}

\section{Introduction}

Small animal species (e.g. mouse) have a faster heart rate than large animal species (e.g. human). A typical heart rate for a human is $\sim 72$ beats per minutes (bpm). A rabbit has a heart rate of $\sim 205 \mathrm{bpm}$. A rat has a heart rate of $\sim 420 \mathrm{bpm}$. A mouse has a heart rate of $\sim 670 \mathrm{bpm}$. Although, the size of the mammalian heart varies according to the size of the animal, its structure is the same. Therefore, what makes a small mammalian heart beat faster than a larger mammalian heart? The heart beat is initiated and controlled by an electrical impulse, the cardiac action potential. The action potential is initiated by the sinus node, the pacemaker of the heart.

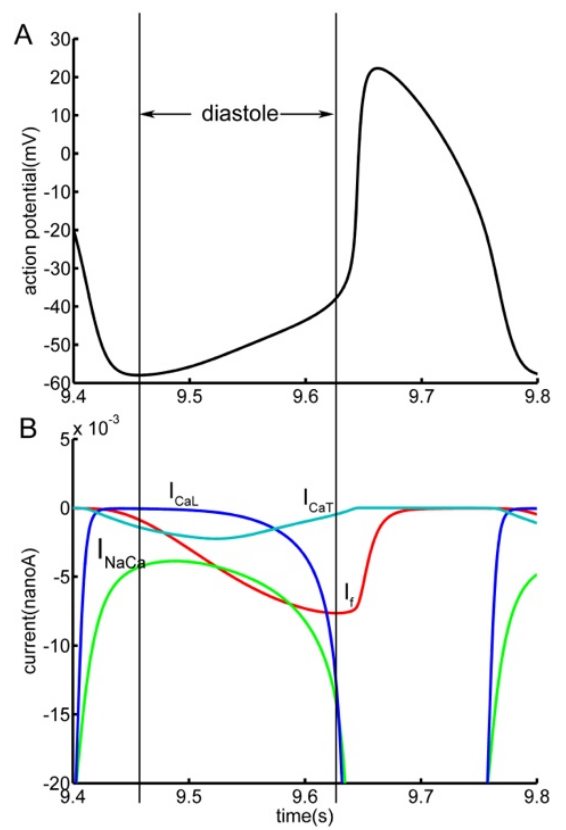

Figure 1. A, rabbit sinus node action potential. B, inward currents during diastole (pacemaker phase).

The action potential is generated by the movement of ions through transmembrane ion channels in cardiac cells. In the sinus node, the pacemaker potential (the main determinent of the heart rate) is the slow, positive increase of membrane potential that occurs in diastole between the end of one action potential and the beginning of next action potential (Figure 1A). It is also called diastolic depolarization. Figure $1 \mathrm{~B}$ shows the main inward ionic currents $\left(\mathrm{I}_{\mathrm{f}}, \mathrm{I}_{\mathrm{NaCa}}, \mathrm{I}_{\mathrm{Ca}, \mathrm{L}}\right.$ and $\left.\mathrm{I}_{\mathrm{Ca}, \mathrm{T}}\right)$ responsible for the diastolic depolarization.

In this study, we investigated heart rate control from the functional level to the gene level in human, rabbit, rat and mouse using a 'meta-analysis' approach. 


\section{Methods}

We have collected and reviewed literature about the sinus node cell action potential, as well as expression of ion channels.

\subsection{Comparison of sinus node cell action potentials in human, rabbit, rat and mouse}
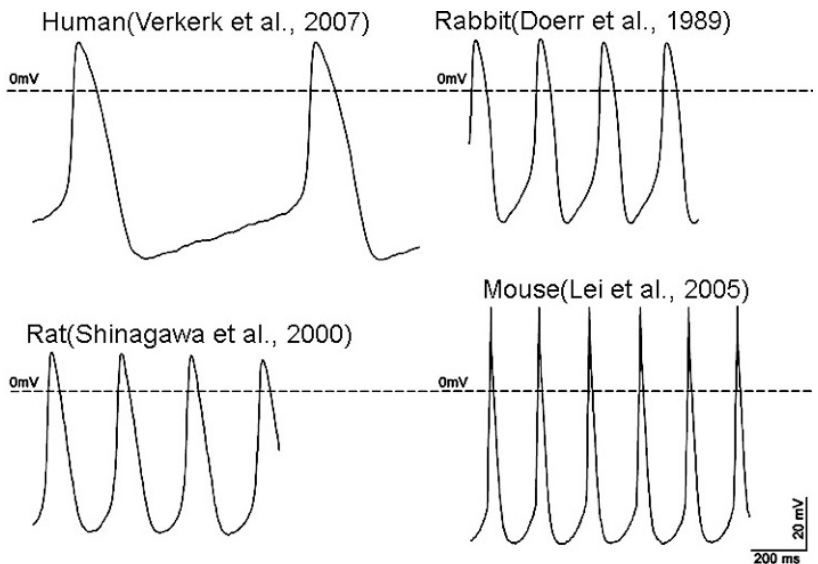

Figure 2. Spontaneous action potentials recorded from sinus node cells isolated from human, rabbit, rat and mouse.

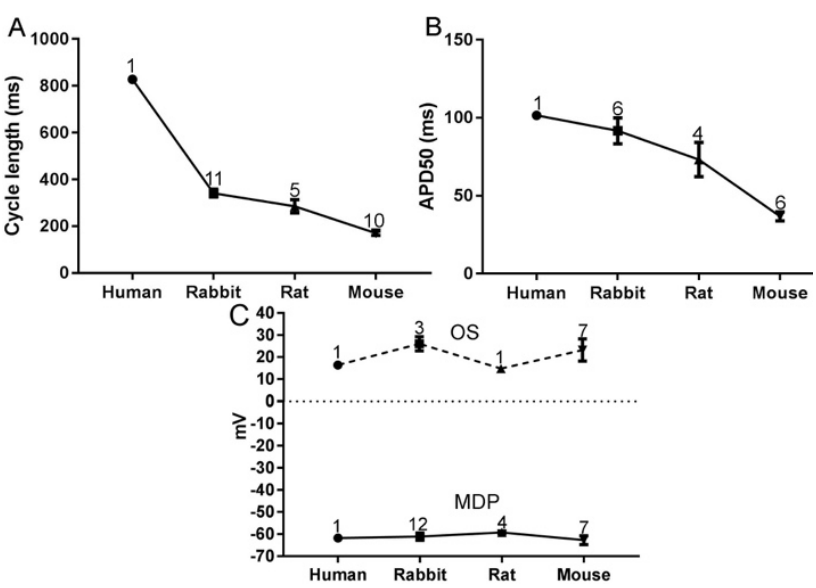

Figure 3. Cycle length (A), $\mathrm{APD}_{50}$ (B) , overshoot (OS) and maximum diastolic depolarization (MDP) of sinus node cells isolated from human, rabbit, rat and mouse. Numbers indicate the number of studies data are taken from.

We have reviewed studies reporting the action potential characteristics of single sinus node cells isolated from human, rabbit, rat and mouse. There is only one study on human sinus node cells [1]. Figure 2 shows examples of spontaneous action potentials of isolated sinus node cells from human, rabbit, rat and mouse. Figure 3 compares the cycle length (time between spontaneous action potentials), action potential duration at $50 \%$ repolarization $\left(\mathrm{APD}_{50}\right)$, action potential overshoot (OS) and maximum diastolic depolarization (MDP) of sinus node cells from the four species. It shows clearly that, the bigger the size of the mammal, the longer the cycle length and action potential duration (Figure 3A,B). However, the action potential overshoot and maximum diastolic potential show no substantial species differences (Figure 3C).

2.2. Comparison of ionic currents ( $I_{f}$, $\mathbf{I}_{\mathrm{NaCa}}, \mathrm{I}_{\mathrm{Ca}, \mathrm{L}}$ and $\mathrm{I}_{\mathrm{Ca}, \mathrm{T}}$ ) in sinus node cells from human, rabbit, rat and mouse

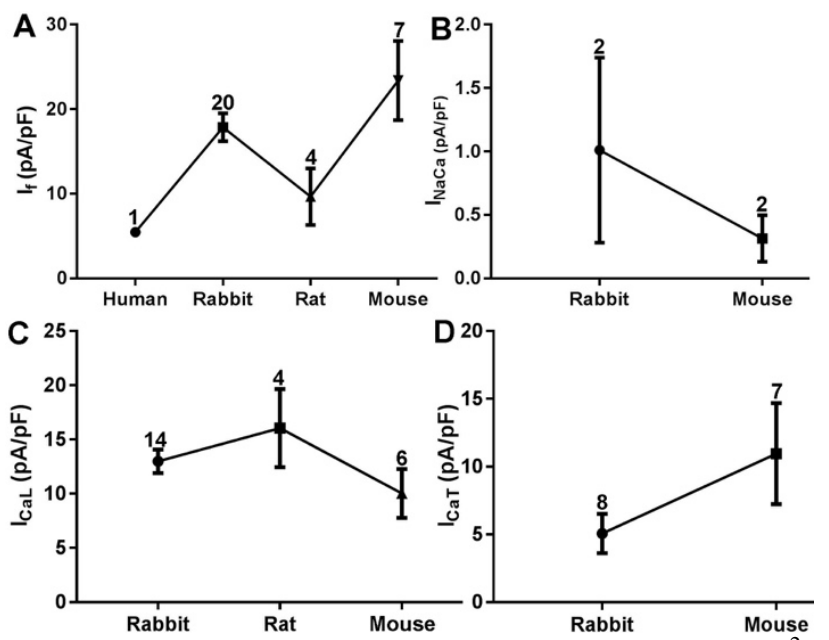
Figure 4. Density of funny current $\left(\mathrm{I}_{\mathrm{f}} ; \mathrm{A}\right), \mathrm{Na}^{+}-\mathrm{Ca}^{2+}$ exchange current $\left(\mathrm{I}_{\mathrm{NaCa}} ; \mathrm{B}\right)$, L-type $\mathrm{Ca}^{2+}$ current $\left(\mathrm{I}_{\mathrm{Ca}, \mathrm{L}} ; \mathrm{C}\right)$ and T-type $\mathrm{Ca}^{2+}$ current $\left(\mathrm{I}_{\mathrm{Ca}, \mathrm{T}} ; \mathrm{D}\right)$ in sinus node cells from different species. Numbers indicate the number of studies data are taken from.

We have reviewed studies reporting recordings from single sinus node cells of inward currents $\left(\mathrm{I}_{\mathrm{f}}, \mathrm{I}_{\mathrm{NaCa}}, \mathrm{I}_{\mathrm{Ca}, \mathrm{L}}\right.$ and $\mathrm{I}_{\mathrm{Ca}, \mathrm{T}}$ ) known to flow during diastolic depolarization. $\mathrm{Q}_{10}$ was used to correct temperature differences among studies. Funny current $\left(\mathrm{I}_{\mathrm{f}}\right)$ density is higher in the rabbit ( $\sim 3.3$ times) and mouse ( $\sim 5$ times) than in the human (Figure 4A). However, $\mathrm{Na}^{+}-\mathrm{Ca}^{2+}$ exchange current $\left(\mathrm{I}_{\mathrm{NaCa}}\right)$ density is similar in the rabbit and mouse (Figure 4B). Although the L-type $\mathrm{Ca}^{2+}$ current $\left(\mathrm{I}_{\mathrm{Ca}, \mathrm{L}}\right)$ density is similar in the rabbit, rat and mouse (Figure 4C), T-type $\mathrm{Ca}^{2+}$ current $\left(\mathrm{I}_{\mathrm{Ca}, \mathrm{T}}\right)$ density is higher in the mouse $(\sim 2 \times)$ than in the rabbit (Figure 4D).

\subsection{Comparison of the channel mRNA expression in the sinus node of human, rabbit, rat and mouse}

We have collected data (from quantitative PCR, qPCR) on ion channel mRNA expression in the sinus node for the four species from different research groups (Table 1). 
To compare data, we either normalised to the $\mathrm{Na}_{\mathrm{v}} 1.5$ mRNA level in atrial muscle (we assumed that the $\mathrm{Na}_{\mathrm{v}} 1.5$ mRNA level in atrial muscle is the same in the four species) or the $\mathrm{Ca}_{\mathrm{v}} 1.2$ mRNA level in the sinus node (we assumed that the $\mathrm{Ca}_{\mathrm{v}} 1.2$ mRNA level in the sinus node is the same in the four species). Although different housekeeper genes were used (18S, 28S, HPRT), comparison of different data sets on the same tissue but with different housekeeper genes suggests that this is unimportant.

Table 1. Experimental (qPCR) studies used in this analysis.

\begin{tabular}{|c|c|c|}
\hline Study & Species & Housekeeper \\
\hline Chandler et al. (2009) [2] & Human & 28S \\
\hline Tellez et al. (2006) [3] & Rabbit & HPRT \\
\hline Yanni \& Cai (unpublished) & Rabbit & 28S \\
\hline Tellez et al. (unpublished) & Rat & $18 \mathrm{~S}$ \\
\hline Tellez et al. (unpublished) & Rat & $18 \mathrm{~S}$ \\
\hline $\begin{array}{c}\text { Marionneau \& Lei (2005) } \\
\text { [4] }\end{array}$ & Mouse & HPRT \\
\hline Hao \&Lei (unpublished) & Mouse & HPRT \\
\hline
\end{tabular}

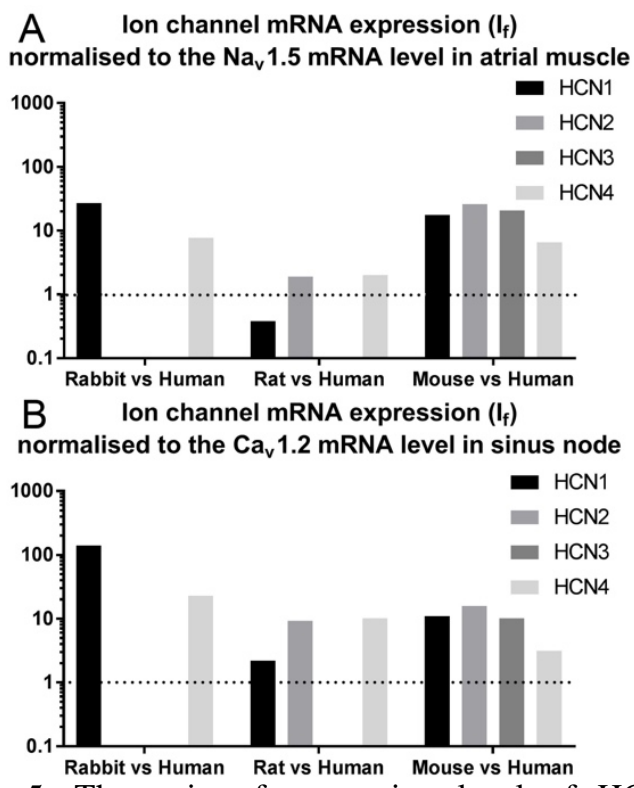

Figure 5. The ratio of expression level of HCN1 4 (responsible for $\mathrm{I}_{\mathrm{f}}$ ) in the sinus node of rabbit, rat and mouse to human. A, expression normalised to the $\mathrm{Na}_{\mathrm{v}} 1.5$ mRNA level (in atrial muscle). B, expression normalised to the $\mathrm{Ca}_{\mathrm{v}} 1.2$ mRNA level (in sinus node). Dotted line is the line of no difference (ratio=1).

Figure 5 compares the expression level of HCN1 4 (responsible for the funny current, $\mathrm{I}_{\mathrm{f}}$ ) in the sinus nodes of rabbit, rat and mouse to expression in the sinus node of human using the ratio of the expression level in the sinus node of the small mammal to the expression level in the sinus node of the human. The dotted line indicates equal expression. HCN expression in rabbit and mouse sinus node are substantially higher than in human sinus node (Figure 5). When comparing rat and human sinus node, different results were obtained with the different normalising methods (Figure 5).
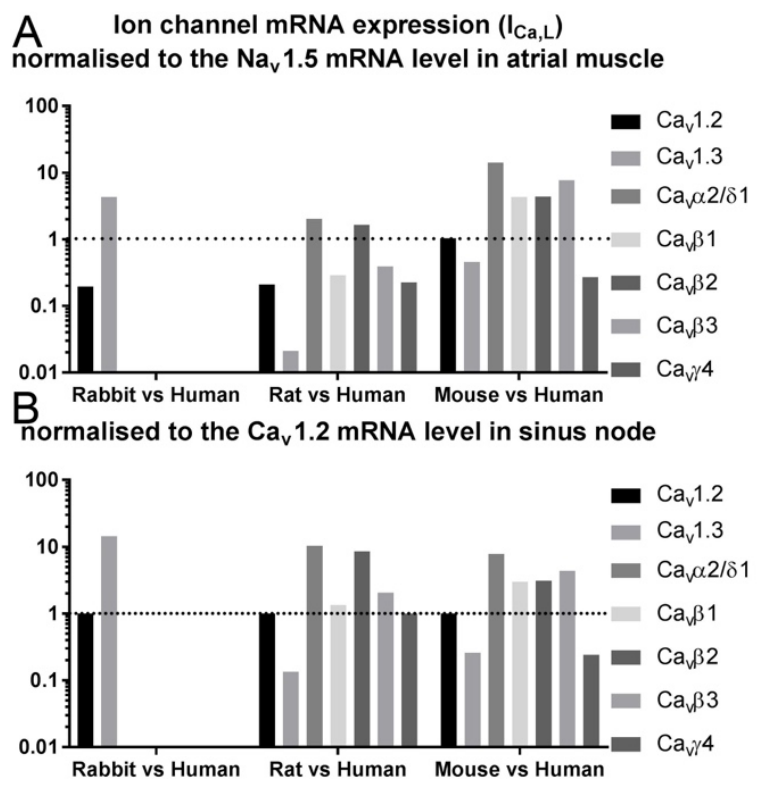

Figure 6 . The ratio of expression level of $\mathrm{Ca}_{\mathrm{v}} 1.2, \mathrm{Ca}_{\mathrm{v}} 1.3$, $\mathrm{Ca}_{\mathrm{v}} \alpha 2 / \delta 1, \mathrm{Ca}_{\mathrm{v}} \beta 1 \sim 3$ and $\mathrm{Ca}_{\mathrm{v}} \gamma 4$ (responsible for $\mathrm{I}_{\mathrm{Ca}, \mathrm{L}}$ ) in the sinus node of rabbit, rat and mouse to human. A, expression normalised to the $\mathrm{Na}_{\mathrm{v}} 1.5$ mRNA level (in atrial muscle). $\mathrm{B}$, expression normalised to the $\mathrm{Ca}_{\mathrm{v}} 1.2$ mRNA level (in sinus node). Dotted line is the line of no difference (ratio=1).

Figure 6 shows the comparison of the expression level of the ion channels responsible for the L-type $\mathrm{Ca}^{2+}$ current $\left(\mathrm{I}_{\mathrm{Ca}, \mathrm{L}}\right)$ in the sinus nodes of the small mammals and human. $\mathrm{Ca}_{v} 1.2, \mathrm{Ca}_{v} 1.3, \mathrm{Ca}_{v} \alpha 2 / \delta 1, \mathrm{Ca}_{v} \beta 1 \sim 3$ and $\mathrm{Ca}_{v} \gamma 4$ showed little species differences.

Figure 7A,B shows the comparison of the expression level of the molecules $\left(\mathrm{Ca}_{\mathrm{v}} 3.1\right.$ and NCX2) responsible for the T-type $\mathrm{Ca}^{2+}$ current $\left(\mathrm{I}_{\mathrm{Ca}, \mathrm{T}}\right)$ and $\mathrm{Na}^{+}-\mathrm{Ca}^{2+}$ exchange current $\left(\mathrm{I}_{\mathrm{NaCa}}\right)$ in the sinus nodes of the small mammals and human. $\mathrm{Ca}_{\mathrm{v}} 3.1$ expression in rat and mouse sinus node is substantially higher than in human sinus node, but there is little or no difference between rabbit and human. NCX1 expression in rabbit sinus node is substantially higher than in human sinus node, but there is little or no difference between rat and human, and mouse and human.

Figure 7C,D shows the comparison of the expression level of $\mathrm{Ca}^{2+}$-handling molecules (Serca2a and RYR2) responsible for sarcoplasmic reticulum $\mathrm{Ca}^{2+}$ uptake and $\mathrm{Ca}^{2+}$ release in the sinus nodes of the small mammals and human. The Serca2a expression in rabbit, rat and mouse sinus nodes is substantially higher than in human sinus node. The RYR2 expression in rat and mouse sinus nodes 
is higher than in human sinus node, but there is little or no difference between rabbit and human sinus nodes.

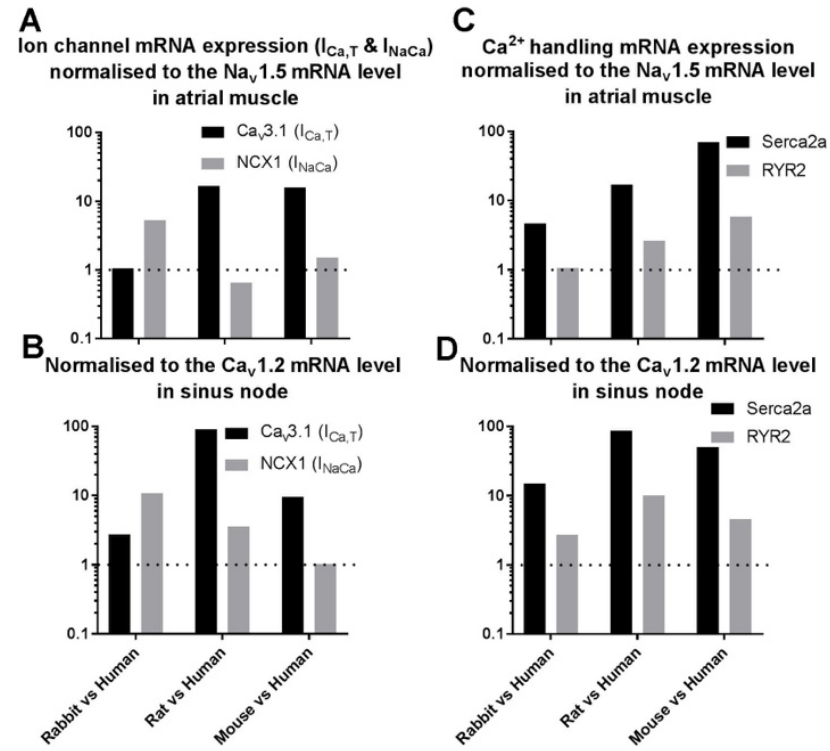

Figure 7. A and B, the ratio of expression level of $\mathrm{Ca}_{\mathrm{v}} 3.1$ (responsible for $\mathrm{I}_{\mathrm{Ca}, \mathrm{T}}$ ) and NCX1 (responsible for $\mathrm{I}_{\mathrm{NaCa}}$ ) in the sinus node of rabbit, rat and mouse to human. A, expression normalised to the $\mathrm{Na}_{\mathrm{v}} 1.5$ mRNA level (in atrial muscle). $\mathrm{B}$, expression normalised to the $\mathrm{Ca}_{\mathrm{v}} 1.2$ mRNA level (in sinus node). C and D, the ratio of expression level of Serca2a (responsible for sarcoplasmic reticulum $\mathrm{Ca}^{2+}$ uptake) and RYR2 (responsible for sarcoplasmic reticulum $\mathrm{Ca}^{2+}$ release) in the sinus node of rabbit, rat and mouse to human. $\mathrm{C}$, expression normalised to the $\mathrm{Na}_{\mathrm{v}} 1.5$ mRNA level (in atrial muscle). D, expression normalised to the $\mathrm{Ca}_{\mathrm{v}} 1.2 \mathrm{mRNA}$ level (in sinus node). Dotted line is the line of no difference (ratio=1).

\section{Discussion and conclusion}

Funny current ( $\left.\mathrm{I}_{\mathrm{f}}\right)$ is an important pacemaker current. The data on $\mathrm{I}_{\mathrm{f}}$ density and the underlying ion channel (HCN) expression indicate that $\mathrm{I}_{\mathrm{f}}$ is larger in mouse sinus node than human sinus node (Figures $4 \mathrm{~A}$ and 5 ). $\mathrm{I}_{\mathrm{f}}$ is $\sim 5 \times$ higher in mouse than in human. HCN1 4 are $\sim 18 \times, \sim 26 \times$, $\sim 21 \times$ and $\sim 7 \times$ higher in mouse than in human. The densities of the L-type $\mathrm{Ca}^{2+}$ current and $\mathrm{Na}^{+}-\mathrm{Ca}^{2+}$ exchange current $\left(\mathrm{I}_{\mathrm{Ca}, \mathrm{L}}\right.$ and $\left.\mathrm{I}_{\mathrm{NaCa}}\right)$ are not available for human sinus node. However, the data from animal experiments (both for current densities and expression) suggest that there are no significant differences (Figures 4B,C, 6, and 7A,B). The T-type $\mathrm{Ca}^{2+}$ current $\left(\mathrm{I}_{\mathrm{Ca}, \mathrm{T}}\right)$ also plays a role in pacemaking. The density of $\mathrm{I}_{\mathrm{Ca}, \mathrm{T}}$ and the underlying $\mathrm{Ca}_{\mathrm{v}} 3.1$ expression are higher in mouse sinus node than in rabbit sinus node (Figures 4D and 7A,B). In addition, $\mathrm{Ca}_{\mathrm{v}} 3.1$ expression is $\sim 16 \times$ higher in mouse sinus node than in human sinus node (Figure 7A). Intracellular
$\mathrm{Ca}^{2+}$ plays a role in pacemaking (the so-called ' $\mathrm{Ca}^{2+}$ clock') and the expression of the $\mathrm{Ca}^{2+}$-handling molecules, Serca2a and RYR2, is $\sim 70 \times$ and $\sim 6 \times$ higher in mouse sinus node than in human sinus node (Figure 7C).

We conclude that the mouse heart rate is faster than that of the human, because in the sinus node the molecules responsible for $\mathrm{I}_{\mathrm{f}}, \mathrm{I}_{\mathrm{Ca}, \mathrm{T}}$ and intracellular $\mathrm{Ca}^{2+}-$ handling are more highly expressed in mouse.

\section{Limitation}

The data collected are from studies from different groups, and the experimental conditions and the age of animals used were different. The number of studies is limited in some cases. For example, there is only one experimental study concerning $\mathrm{I}_{\mathrm{f}}$ in the human sinus node cell [1]. We analysed data on ion channel expression using two normalisation methods. The assumptions underlying these two methods have not been validated.

\section{Acknowledgements}

This study is supported by a British Heart Foundation programme grant (RG/11/18/29257).

\section{References}

[1] Verkerk AO, Wilders R, van Borren MMGJ, Peters RJG, Broekhuis E, Lam K, Coronel R, de Bakker JMT, Tan HL. Pacemaker current $\left(\mathrm{I}_{\mathrm{f}}\right)$ in the human sinoatrial node. Eur Heart J 2007;28:2472-8.

[2] Chandler NJ, Greener ID, Tellez JO, Inada S, Musa H, Molenaar P, DiFrancesco D, Baruscotti M, Longhi R, Anderson RH, Billeter R, Sharma V, Sigg DC, Boyett MR, Dobrzynski H. Molecular architecture of the human sinus node: insights into the function of the cardiac pacemaker. Circulation 2009;119:1562-75.

[3] Tellez JO, Dobrzynski H, Greener ID, Graham GM, Laing E, Honjo H, Hubbard SJ, Boyett MR, Billeter R. Differential expression of ion channel transcripts in atrial muscle and sinoatrial node in rabbit. Circ Res 2006;99:1384-93.

[4] Marionneau C, Couette B, Liu J, Li H, Mangoni ME, Nargeot J, Lei M, Escande D, Demolombe S. Specific pattern of ionic channel gene expression associated with pacemaker activity in the mouse heart. Journal of Physiology 2005;562:223-34.

Address for correspondence:

Dr. Jue Li

Cardiovascular Sciences, University of Manchester, CTF Building, 46 Grafton Street, Manchester M13 9NT, UK jue.li@manchester.ac.uk 